\title{
Contribution of an innovation platform to change the management of collective irrigation: a case study from the Office du Niger (Mali)
}

\author{
Lassine Soumano* and Mamoudou Traoré \\ Institut polytechnique rural de formation et de recherche appliquée (IPR/IFRA), Katibougou, Mali
}

\begin{abstract}
In the Office du Niger large rice farming irrigation scheme in Mali, water management has been a permanent source of tension between the smallholder tenants and the administration. The transfer of tertiary canal maintenance to the tenant farmers was expected to improve water management but, in practice, that rather led to deterioration. An innovation platform, erected by the CoS-SIS (Convergence of Sciences - Strengthening Innovation Systems) Program, reached a consensual agreement to transfer the maintenance of tertiary canals to the tenant producers, and updated the Contrat Plan expropriation rules for failure to pay water fees as well as many other key dispositions ruling duties and responsibilities for all parties: farmers, Office du Niger agents and the State.
\end{abstract}

Keywords: land management / water management / institutional innovation / innovation platform

\begin{abstract}
Résumé - Contribution d'une plateforme d'innovation au changement dans la gestion de l'irrigation collective : un exemple à l'Office du Niger (Mali). Dans les vastes rizières de l'Office du Niger au Mali, la gestion de l'eau a longtemps été une source de tension entre les petits exploitants et l'administration. Le transfert partiel de cette gestion, avec une répartition de la maintenance des canaux entre les petits exploitants, l'Office du Niger et l'État n'a pas vraiment permis d'atteindre de meilleurs résultats. Une plateforme d'innovation établie par le programme CoS-SIS (Convergence of Sciences-Strengthening Innovation Systems) a abouti à un accord consensuel conférant le nettoyage des canaux tertiaires aux petits exploitants. Elle a aussi actualisé les règles d'expulsion des exploitants en cas de non-paiement de la redevance eau et a modifié les dispositions clefs du Contrat Plan qui régit les tâches et les responsabilités des exploitants, du personnel de l'Office du Niger et de l'État.
\end{abstract}

Mots clés : gestion de l'eau / innovation institutionnelle / plateforme d'innovation

This paper draws on a case study in a large scale irrigation scheme, the Office du Niger, located in the central delta of the Niger River in Mali. The study focused both on terms of the functioning of the IP (Klerkx et al., 2010; Van Paassen et al., 2013), and on terms of how purposeful changes were brought about by IP's activities. This article discusses the causal relation between the IP's actions and the immediate effects. Long-term impacts and consequences were not studied. The IP sought through iterative cycles of action researching built around institutional experiments, participatory inquiries, and shared reflections, to bring about institutional changes supportive of small farmers and the functioning of the irrigation scheme. The institutional experiments were conceived both as a form of joint learning and as a way of

\footnotetext{
* Corresponding author: 1sno2002@yahoo.fr
}

finding innovative ways to resolve or by-pass the sociotechnical and institutional dilemmas revealed by a prior diagnostic study (Nederlof and Pyburn, 2012).

\section{Context}

The Office du Niger (ON) was created in 1932, in the central delta of Niger River. The area supplies $52 \%$ of national rice production as well as significant amounts of vegetables. Despite the ON's important role in the national economy and its contribution to food security, farmers' revenue declined. In response, the government introduced a number of reform measures throughout a process of privatisation and decentralisation with the creation of village associations, users' organisations at the tertiary canals level, and water and land attribution at the field level. Above all, the Government launched a 
multi-stakeholder negotiating and planning process, under the Director of the ON, to elaborate a protocol, known as the Contrat Plan, regulating the governance of the scheme. The Contrat Plan defines the relations among the three main sets of actors: the tenants, the $\mathrm{ON}$, and the Government, with the injunction for all parties to take more account of the human and social aspects of irrigation management, and to encourage especially the small scale producers to play a new role in decision-making and management. These reforms were not up to the standard (Office du Niger, 2008).

The withdrawal of the State from the management of the ON necessitated the revision of the relationship among the actors responsible for water management. That was stipulated in the first Contrat Plan in 1994. It was assumed that the Plan expressed everyone's interests, but performance did not significantly improve, because of a lack of incentive measures to bring about the desired collective action on the part of tenants (Vandersypen et al., 2007; Vandersypen et al., 2009).

The agreed obligations of the three main parties to the Contrat Plan were as follows:

- farmers (tenants): cultivate the land allocated to the family; adhere to the advice given by the extension service; pay the water user fee; maintain the tertiary canals; pay their land user duty;

- ON: provide water throughout the ON command area; manage the land resources; provide advisory and other services to the tenants and ensure the provision of inputs and other agricultural materials; maintain the structures of the secondary canal network and roads; assure the security and growth of the agricultural output of the scheme;

- the state: ensure the legal and economic protection of the farmers, provide $\mathrm{ON}$ with funds for investment and to support its functions.

The results were as follows:

- many tenants did not perform adequately, or not on time, the periodic cleaning of the tertiary canals, a task that was previously carried out by ON. They received no instruction or equipment to help them in their new task and were mostly ignorant of the fact that this was now supposed to be their responsibility. Although represented by leading farmers in the negotiation of the Contrat Plan, which in any case was written in French, the language of the elite, the majority of small tenant farmers felt that their interests were neglected;

- ON discovered that fulfilling its own commitments depended on the tenants' fulfilling theirs. For instance, if the tenants did not pay in time or in full the fee charged for the use of water, ON, in turn, experienced revenue shortfalls and struggled to meet its own obligations. It often failed to carry out its own responsibilities on time, or at all, and thus provided little incentive for the tenants to carry out their own contractual obligations;

- the subsidy provided to ON by the Government often did not arrive on time or was insufficient to cover ON's needs. The scheme managers had no powers to compel the Government to meet its financial obligation.

In the lack of strong evidence that the $\mathrm{ON}$ reform measures were leading to greater efficiency and a higher productivity, the Government began to question continued provision of support to the scheme.

\section{Methodology}

From early 2010 to the end of 2013, an inter-university collaboration programme, the Convergence of SciencesStrengthening Innovation Systems (CoS-SIS), provided an opportunity for state actors, tenants and researchers to address the situation through setting up an innovation platform (IP) (Hounkonnou et al., 2012; Jiggins et al., 2016b) in the Niono and Molodo irrigation zones. At the beginning, the IP was composed of individuals known through the diagnostic study to be interested in seeking a way out of the difficulties identified, drawn from three stakeholder categories: value chain actors (5 small scale tenant farmers, 2 members of farmers' cooperatives); regulators (2 from local bureaux of the $\mathrm{ON}$ at Niono and Molodo), and service providers (1 from IER [Rural Economy Institute], and 1 from a non-government organisation, Nyeta-Conseil).

The IP was facilitated by a part-time member from IER, who also became responsible for the CoS-SIS local project. The Research Associate (RA) periodically met the other CoSSIS RAs and national coordinators from Mali, Benin and Ghana to present and jointly analyse interim results, resolve facilitation challenges, and review any changes in various domains and in national and international affairs that affected operations in the field. The IP was also supported by a National Coordinator, and a National Programme Management Team, comprising of leading individuals in the domain of water management and agriculture, who had personal and professional links at the highest levels of the administration and the government. Both of them, from time to time, visited the IP 'in the field', discussed interim results with ON officials, and sought to spread the emergent information into national networks of influence.

The preliminary diagnostic study was carried out in three sites chosen by Niono Zone ON officers and CoS-SIS researchers: the villages of Kouyan-coura (Niono), Kangaba/ M3 (Molodo), and Tugan-coura (Kolongo) (Doumbia et al., 2012). The process comprised: non-participant observations on irrigation and drainage practices at the tertiary level and below, field visits of extension agents to farmers, survey of farmers at the tertiary level, and discussions of the results with village-chiefs and other community members at assemblies held in each village.

The study had two interwoven strands: (a) experimental activities and inquiries supported by the IP presented in this article (Sect. 3); and (b) a theory-guided process inquiry (TGPI) (Faletti and Lynch, 2009) carried out by the part-time Research Associate (RA) (Jiggins et al., 2016a). In addition to facilitating the work of the IP, the RA was responsible for recording the TGPI data and processing the information throughout the study period so as to provide reasonable causal evidence for the changes documented.

Two cause and effect hypotheses were adopted across the programme: either the IP itself, as a multi-actors' institutional innovation was causing the observed effects; or the power relationships within IP and external to the IP that, best explained the observed effects.

The IP was initiated in 2010 by a scoping study of the water management domain in the ON. A national workshop of agricultural experts and other stakeholders decided to position the IP at the Niono municipality in Ségou Region. It focuses on 
Niono and Molodo irrigation zones. Individuals were invited to participate 'in their own persons' rather than as 'representatives' of their organisations, in the expectation that this might minimize inter-organisational disagreements and the constraints of defending official points of view (Nederlof and Pyburn, 2012).

As part of the process of getting to know each other, the members, first, analysed the relationships among the key organisational actors (actor linkage diagram). The formal relationships between the $\mathrm{ON}$ and the tenants, and between individual tenants and their local communities, both supposedly structured by the Contrat Plan, dominated their analysis. However, as one of the first 'institutional discoveries' made by IP members, they also noted that the visualisation of 'how things are supposed to work' hid the real informal relationships that existed among these identified entities, and yet they offered greater insight into how 'things really worked'.

The IP members next analysed in depth the institutions that sustained and indeed added to the tensions between the tenants and the $\mathrm{ON}$ administration, identified from their own experiences, ON reports, and research studies. 'Institutions' were distinguished from 'organisations', and defined as encompassing formal and informal laws and rules, norms, and routine practices in the use of socio-technologies and in sense-making (Struik and Klerkx, 2014). Sense-making was taken to include people's largely un-evidenced assumptions about 'how things worked', the kinds of information that were taken into account (by whom), and contrasting frames of interpretation. Table 1 highlights the institutions that the IP subsequently sought to change. From the end of 2012 onwards, in their further discussions and analyses of institutional change, they used the categories by which Avelino and Rotmans (2009) and Fuchs and Graab (2011) had sorted and grouped institutions, under the headings of legitimation, material structures, and significance/sense-making. We return to these categories in the next two sections.

The IP noted how the reform measures expressed in the Contrat Plan were compromised and constrained by the regime prevailing at the study sites. Bringing a change in the regime, primarily by means of iterative cycles of actionresearching was necessary. The experiment in canal cleaning was an 'entry point' for this effort.

\section{Results}

\subsection{The initial institutional experiment}

Failure to comply with the tertiary canal cleaning obligations and related water management tasks arose. The IP concluded that in these conditions, stronger effort to reinforce the official rules or, alternatively, to seek to 'motivate' farmers to perform their duties, would be ineffective. They suggested instead, in discussion with the RA, a process of experiment-based learning among all those who needed to coordinate their actions if water management was to be improved. The IP invited in the learning group: officials from ON, researchers from the Institute of Rural Economics, the president of the IP in his capacity of a member of the official council representing the communes, the tenants union, the head of the farmers' association, Sexagon (a farmer representative, permanent member of the committee in charge of revising the Contrat Plan), and the NGO Alphalog.

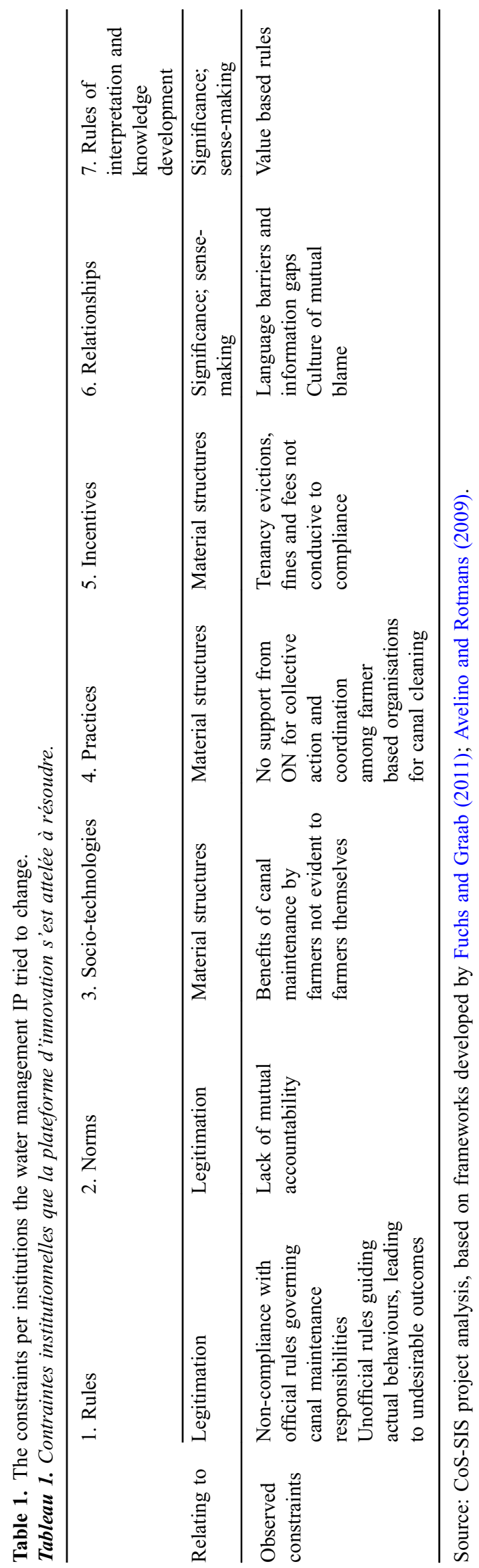

Page 3 of 7 


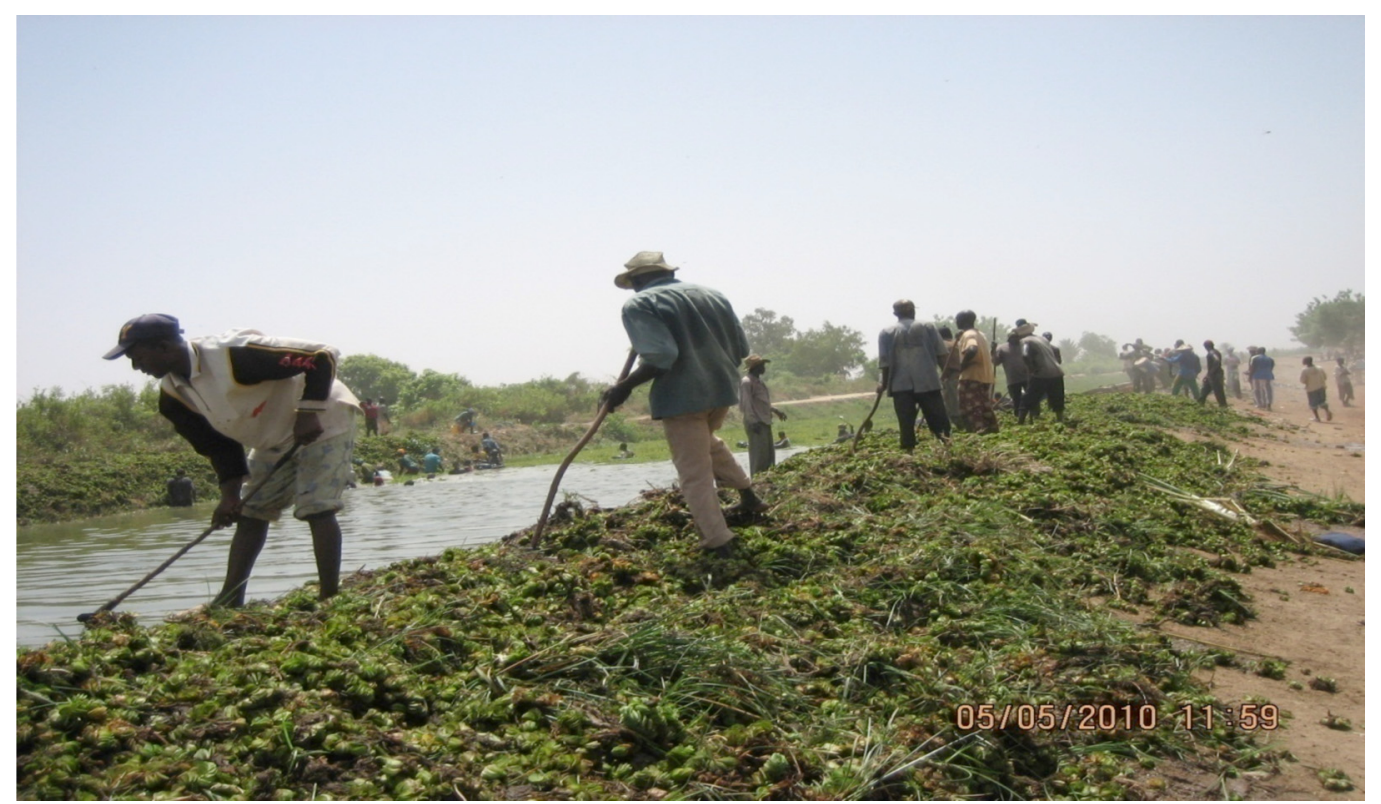

Fig. 1. Cleaning of irrigation canal organised by a process champion. Photo credit: L. Soumano.

Fig. 1. Nettoyage d'un canal d'irrigation organisé par un leader du processus de changement.

Accompanied by the RA, the IP members visited the site of the experiment before, during and after, to observe and discuss the results and their implications.

A section of poorly maintained canal and associated water and drainage channels were identified, as well as the rice fields irrigated from these infrastructures. They then separated this into a part in which the farmers undertook the cleaning and followed the recommended water management and cultivation practices during the next rice season, and a part where no cleaning would take place and farmers would carry on observations as usual (the control sector). The resulting water flow and availability (timing and volume), areas cultivated, weed control, and paddy yields, were measured at appropriate time throughout the experiment. The farmers themselves agreed to make the necessary arrangements to ensure that everyone would participate in the cleaning work at the treatment site (Fig. 1).

At the treatment site, water flow and clarity increased; farmers received sufficient water and on time; most farmers cultivated their entire plots; paddy yields increased. In the control plot, poor management of land and crops persisted with the usual poor outcomes.

The participating farmers from both the treated and control areas, and the organisations representing their interests, claimed their strong motivation by the results and they were ready to encourage other farmers to develop a capability to manage land and water resources for their own benefit, in line with the responsibilities and tasks assigned to them under the Contrat Plan. It was not easy to persuade everyone, especially the larger farmers, to carry out the necessary work, while others were unavoidably absent on other business (such as funerals) on the agreed date. This raised issues of fairness. There were two options to resolve this institutional dilemma: allowing those who wished to absent themselves to pay for hiring labourers in their place; and for the $\mathrm{ON}$, to resume responsibility for cleaning the tertiary canals, with farmers making a cost-sharing contribution in the form of a levy to be included in the water fee. Although these suggestions had been proposed already by previous research (Vandersypen et al., 2007; Passouant et al., 2010), little change had resulted. In our case, the TGPI data allowed us to track what happened in consequence, as presented in the next two sections.

\subsection{Elaborating and negotiating local conventions}

From the farmers' point of view, fulfilment of the ON's expectations of how the Contrat Plan would actually work was blocked by three key institutional constraints. Various suggestions made were reviewed and assessed by the learning group and IP members. Any new arrangements that were collectively accepted, then, were encoded formally in written documents known as 'conventions' i.e. setting out the provisions and measures endorsed in public assemblies, and hereafter applied throughout the case study zones. Local conventions were subsequently incorporated in the new Contrat Plan as follows: canal cleaning.

The IP began with examining the legal articles governing water management since 1996, regarding the allocation of responsibilities for water management by means of a devolution of powers from the State to the $\mathrm{ON}$ and then, to the farmers. The IP proposed the $\mathrm{ON}$ resumes responsibility cleaning the tertiary canals, in exchange for a charge that could be included in the water user fees. However, in a series of meetings organised by the IP, farmers cautioned that new mechanisms would be needed to ensure the accountability of the $\mathrm{ON}$ in performing these tasks on time and efficiently, and to control bureaucratic abuse of the additional charge. The ON officials' response was that the proposal was against the spirit and letter of the devolution and liberalisation laws that clearly indicated that the maintenance of the tertiary canal was the farmers' responsibility. However, 
further joint discussions led to an agreement, encoded in a local convention applicable in the study area, that the ON zonal offices would provide support in terms of awareness-raising, equipment and advice, so that the farmers could carry out their collective tasks more efficiently.

\subsection{Water user fees and eviction regulations}

The prevailing rule was that any tenant that failed to pay the whole water use fee, calculated on the basis of the water requirement for rice per allocated ha, would lose access to the entire area. The IP's inquiries revealed that farmers regarded this as unfair, because it left many small farm households in penury. They believed that they should be able to retain the land in proportion to the percentage of the fee paid; and because on eviction they received no compensation for the time, effort and other resources they had contributed to collective tasks such as cleaning drainage ditches and canals from which only the remaining farmers benefited. The IP also discovered that the principle of 'proportional eviction' was commonly allowed for richer farmers having more land. The IP, discussing these findings with the learning group, proposed that 'proportional eviction' should become the standard rule. The ON zonal officials' response was that although it might be difficult to administer on small plots they were willing to try to make it work. The application of the new rule and its effects were monitored by the IP, learning group and ON zonal officials over the next year. Despite encountering some procedural challenges at the end of the year, principally concerning the official registration of how the rule was applied (which plots, applied by whom, for whom, where, when), the effects were agreed by everyone to be positive. Thus, this rule was also encoded as a local convention to guide future practices.

\subsection{Contracts with $\mathrm{ON}$ and land use rights}

In Mali, all the land, in principle, belongs to the State. Land transactions are prohibited in Office du Niger area (purchasing/ selling, renting, sharecropping). However, $16.5 \%$ of lands have been informally sold or rented (Dave, 2008).

The Law for the Orientation of Agriculture provides a "Titre Foncier" (land property title) to a State agency (such as the $\mathrm{ON}$ ) for the purposes of rural and agricultural development.

The family tenants can only get a "Permis d'exploitation agricole" (PEA) from the $\mathrm{ON}$, as long-term leases are out of their reach (Adamczewski et al., 2013); but they would prefer their land use rights to be expressed in the form of an enforceable legal contract.

Informal land transfers and large land lease allocations risk transforming smaller farmers into simple labourers, and to allow richer individuals (whether resident or not, in the ON area) to capture the land and water resources of the ON.

\subsection{Negotiating the incorporation of the conventions into the new Contrat Plan}

The evidence assembled by the IP and the learning group, and the resulting conventions, were formally presented to $\mathrm{ON}$ officials in Niono, for consideration in the revision of key clauses of the new Contrat Plan.
In fact, since the 1994 revision, the herd movements in and out of the $\mathrm{ON}$ area were not regulated. Animal passages and drinking points have never been planned in ON schedule. They drink from irrigation canals, most of which are muddy structures. Consequently, they damage the canals and producers cannot install plant nurseries until the animals free the $\mathrm{ON}$ zone.

Such a situation permanently brings conflicts between producers and breeders. Thus, the communal authorities developed an "inter-communal convention" to improve the situation. That document revealed to be weak and insufficient

The IP proposed to review the document but some difficulties still exist because the rainy season does not occur at fixed dates. The minutes of the IP meetings recorded how they had pointed out that the 'innovation space', a new acquisition, developed by the IP and the learning groups through action researching, had strengthened small scale farmers' access to existing opportunities by creating new institutional conditions, and by re-shaping the incentives for improved performance by all actors (including ON officials). They argued that the local conventions did not challenge the aims of the $\mathrm{ON}$; rather, the conventions demonstrated 'what works better' and how the multiple, diverse interests of the three main sets of actors might be satisfied.

The IP found that, by constituting the learning group through their action-researching practices, and by facilitating joint reflections on the meaning and implications of the new information generated, they became accepted as legitimate and trustworthy actors in discussion of the new Plan. The IP's farmer members, in particular, reported that they had acquired new standing in their own entities and were treated with greater respect by the other official negotiating parties. Throughout the study period, the RA also had encouraged the IP and learning group members to share, at formal meetings and informally, the emergent information and analyses with members of their personal and professional networks, so that support for encoding the local conventions into the new Contrat Plan became normalised across other zones of the $\mathrm{ON}$ and at higher decision-making levels. The contribution of the national-level to achieving this outcome was also important. In the event, all the conventions were adopted in the new Plan without major amendment.

\section{Analysis and discussions}

In mid 2013, a preliminary analysis revealed a crisis of legitimacy because of mutual misunderstandings arising from the relationship between the structures (col. 6). The development of local conventions opened the door to changes in the practices and in the institutionalised disincentives (cols. 4, 5). Taking into account these experiences together with the evidence of 'what works better', fed into the revision of the Contrat Plan, demonstrating thereby a shift in collective sense-making toward an evidence-based decision-making and interpretation of knowledge (col. 7). This characterisation is similar to the summary of action-researching with partners offered by Faure et al. (2010), and of the results, summarised by Temple et al. (2010). However, the attention paid by the IP to how the results of "action researching" become institutionalised in routine practices, rules and norms is distinctive, and 
draws attention to the explicit effort needed to bring such effects about. Innovation in the institutions holding in place inter-locking socio-technical and institutional behaviours requires effort by actors from within the system of interest to overcome institutional inertia, a point emphasised by Van Paassen et al. (2013). The long-term effects and impacts of the changes brought about, and persistence in current practices, nonetheless, requires follow-up research, that could not be accomplished within the time frame of the CoS-SIS programme.

\subsection{Causal mechanisms}

The IP members, themselves, toward the end of 2013 summarised the achievements in terms of five causal mechanisms:

- intentionality - the IP was conceived for the purposes of a transformational change, to revive an established principle;

- grounding - the entry point for purposeful intervention was empirically-grounded in a prior diagnostic study;

- the IP acted as an independent intermediary with no formal powers - it was composed of individuals motivated to attempt change, whose influence was constituted in a cross scale web of pre-existing formal and informal relationships;

- action-researching - "action-researching" (AR) helped maintain the focus of the IP's agenda on institutional innovation based on information-seeking, evidence-based decision-making, and the codification of new options constituted in the context. AR, in addition, helped build the confidence of the IP as a collective effort that could catalyse purposive change; as their experience of working together matured, the members, over time, took responsibility from the RA for setting the agenda and facilitating their own work;

- the costs of moving change forwards - costs were largely covered by the IP that mobilised personal, professional and official resources through their own networks and organisational contacts.

These five mechanisms suggest: (i) that the IP, in this case, functioned as a catalyst of innovations that were shaped and tested in partnership with other stakeholders; this is not a new finding (see Dulcire et al., 2008; Faure et al., 2010); and, (ii) that catalysing innovation is constituted in the practice of "action-researching"; this also is not a new finding (Albaladejo and Casablanca, 1997). What is new and distinctive, is the way in which the results of AR were codified in local conventions and, eventually, institutionalised in the new Contrat Plan.

The more or less continuous recording of standard data (Jiggins et al., 2016a), repeated peer analysis of the data during IP meetings and at the regional RA meetings, and testing of the data against explicit causal hypotheses throughout the study period, are also uncommon features of a research process focussed on investigating how institutional innovation in agriculture actually comes about. The evidential record provided by this way of researching, in this case, provided strong internal validity of the results by tying effects to causal explanation through time with a reasonable degree of rigour and confidence. However, in the absence of research data assembled by disinterested, non-participant researchers, operating independently from the processes and events recorded, questions could arise of the external validity of the results.

\subsection{What about the IP's future?}

Should an IP become an organization that seeks to perpetuate itself, or is it better seen as only a temporary catalyst?

In 2013, IP members began to question if the IP needed to become one more permanent feature of the $\mathrm{ON}$, continuing to inspire and search for transformational innovations. The ON zonal officials proposed that the IP could become an organizational unit of the Niono Office du Niger administration. However, the IP considered this would compromise both its independence and its intermediary role. This water management IP, thus, began discussing with another IP for crop-livestock integration, also located within the $\mathrm{ON}$ and equally supported by CoS-SIS (Adjei-Nsiah et al., 2013), the feasibility of erecting a co-operative association. The purpose would be to seek funding and offer support to others who, in the future, might also wish to establish an innovation platform. The evident dangers were IPs being seen as the solution to all problematic situations, and/or becoming instruments for the imposition of pre-conceived ideas rather than platforms for joint learning and experimentation.

\section{Conclusions}

The IP can be considered as an effective institutional experiment. It catalysed a significant institutional change through action-researching 'what works better'. The case highlights the context-specificity of such initiatives, and the learning-based pathways through which outcomes emerge. The evidence suggests that an action-researching IP, together with a learning group process, can have no pre-designed outcomes, and that the goals of purposeful change in open societies cannot be steered toward guaranteed results or governed effectively by those distant from the action 'in the field'. Those who are seeking instruments to implement preconceived 'solutions' to irrigation management thus might be unwilling to invest in IPs.

Acknowledgements. We thank the university of Wageningen, The Netherlands, and the Institut d'économie rurale-IER (Mali) for their support to our participation in CoS-SIS, and all our CoS-SIS colleagues. We also thank Office du Niger, the CCRA, local NGOs and individuals for their support.

\section{References}

Adamczewski A, Jamin JY, Burnod P, Boutout Ly EH, Tonneau JP. 2013. Terre, eau et capitaux : investissements ou accaparements fonciers à l'Office du Niger? Cahiers Agricultures 22: 22-32. DOI: 10.1684/agr.2012.0601.

Adjei-Nsiah S., Adu-Acheampong R, Debrah K, Dembelé F, Soumano L, Ouologuem B et al. 2013. Overcoming the bias against the small farm sector in Sub-Saharan Africa: scoping entry points for innovation platforms. Development in Practice 23(7): $857-871$. 
Albaladejo C, Casablanca F (eds.). 1997. La recherche-action: ambitions, practiques, débats. Paris: INRA, Coll. Études et recherches sur les systèmes agraires et le développement.

Avelino F, Rotmans J. 2009. Power in transition: an interdisciplinary framework to study power in relation to structural change. European Journal of Social Theory 12(4): 543-569.

Dave B. 2008. Gestion du foncier à l'ON : de l'identification des problèmes à la recherche d'un nouveau paradigme. Éditions les Cauri d'OR, Revue trimestrielle de l'Université Mandé Bukari, $\mathrm{n}^{\circ} 11-2 \mathrm{~T}$.

Doumbia D, van Paassen A, Oosting SJ, van der Sijpp AJ. 2012. Livestock in the rice-based economy of the Office du Niger. The development potential for increased crop-livestock integration through multi-actor processes. NJAS 60-63:101-114.

Dulcire M, Chia E, Vall É. 2008. Conception des innovations et rôle du partenariat (CIROP). Bilan et perspectives. Synthèse des activités et résultats 2005-2007. Rapport final ATP-CIROP, vol. 1/05. Montpellier: CIRAD.

Faletti TG, Lynch JF. 2009. Context and causal mechanisms in political analysis. Comparative Political Studies 42: 1143-1166.

Faure G, Gasselin P, Triomphe B, Temple L, Hocdé H (eds.). 2010. Innover avec les acteurs du monde rural : la recherche-action en partenariat. Versailles : Quae, Wageningen : CTA, Gembloux: Presses agronomiques de Gembloux.

Fuchs D, Graab K. 2011. Material power and normative conflict in global and local agri-food governance: the lessons of 'Golden Rice' in India. Food Policy 36: 729-735.

Hounkonnou D, Kuyper T, Kossou D, Leeuwis C, Nederlof S, Röling $\mathrm{N}$ et al. 2012. An innovation systems approach to institutional change: smallholder development in West Africa. Agricultural Systems 108: 74-83.

Jiggins J, Essegbey G, Klerkx L, van Paassen A, Pyburn R, Tossou R. 2016a. The use of research in and across nine agro-enterprise domains. The experience of convergence of sciences-strengthening innovation systems in Benin, Ghana and Mali. In: Francis J, van Huis A, Röling N, eds. Innovation systems: toward effective strategies in support of smallholder farmers. Wageningen: Wageningen University/CTA.
Jiggins J, Hounkonnou D, Sakyi-Dawson O, Kossou D, Traoré, M, Röling, N, et al. 2016b. Introduction: innovation platforms to support smallholder development- experiences from Sub-Saharan Africa. Cahiers Agricultures 25(6). DOI: 10.1051/cagri/2016051.

Klerkx L, Aarts N, Leeuwis C. 2010. Adaptive management in agricultural innovation systems: The interaction between innovation networks and their environment. Agricultural Systems 103: 390-400.

Nederlof ES, Pyburn R (eds.). 2012. One finger cannot lift a rock: facilitating innovation platforms to trigger institutional change in West Africa. Amsterdam: KIT Publishers.

Office du Niger. 2008. Contrat Plan exploitants agricoles, 2008-2012. Version finale. Ségou: Office du Niger.

Passouant M, Le Gal P-Y, Keita B. 2010. The contribution of information systems in maintaining large scale irrigation systems. Irrigation \& Drainage 59(3): 241-253.

Struik P, Klerkx L (eds.). 2014. Institutional change towards sustainable agriculture in West Africa. Special Issue. International Journal of Agricultural Sustainability 12(3): 201-382.

Temple L, Casablanca F, Kwa M. 2010. La caractérisation des resultats de la recherche-action en partenariat. In: Faure G, Gasselin $\mathrm{P}$, Triomphe B, Temple L, Hocdé $\mathrm{H}$, eds. Innover avec les acteurs du monde rural : la recherché-action en partenariat. Versailles : Quae, Wageningen : CTA, Gembloux: Presses agronomiques de Gembloux, pp. 157-168.

Vandersypen A, Keita CT, Coulibaly KY, Raes D, Jamin JY. 2007. Formal and informal decision-making on water at the village level: a case study from the Office du Niger Irrigation scheme (Mali). Water Resources Research 43(6): DOI: 10.1029/2006WR005132.

Vandersypen K, Verbist B, Keita ACT, Raes D, Jamin JY, 2009. Linking performance and collective action - the case of the Office $\mathrm{du}$ Niger Irrigation scheme in Mali. Water Resources Management 23(1): 153-168.

Van Paassen A, Klerkx L, Adu-Acheampong R, Adjei-Nsiah S, Ouologuem B, Zannou E, et al. 2013. Choice-making in facilitation of agricultural innovation platforms in different contexts in West Africa: experiences from Benin, Ghana and Mali. Knowledge Management for Development Journal 9(3): 79-94.

Cite this article as: Soumano L, Traoré M. 2017. Contribution of an innovation platform to change the management of collective irrigation: a case study from the Office du Niger (Mali). Cah. Agric. 26: 45003. 